\title{
NEW CHALLENGES FOR AUDITORS IN FORMING AN OPINION AND DISCLOSING INFORMATION ON THE MANAGEMENT REPORT OF FINANCIAL STATEMENTS OF BANKS
}

\begin{abstract}
Adela Socol ${ }^{1}$
ABSTRACT: In the last years improving disclosure effectiveness has become a priority issue in financial reporting of banks. The purpose of this paper is to explore ways to improve financial reporting disclosure studying auditors' attitude in forming an opinion on Management report of banks (Administrators' report). First three banks by assets size from Romania were studied in order to identify the differences and similarities between format/structure and contents of Management report of banks, based on the financial statements for the financial period that ended on 31 December 2015. The focus is on auditors' professional judgment in determining the most adequate considerations and concerns when expressing their opinion on financial statements based on Management report of audited entity. We analysed the banks' options in adopting a proper format and structure of management report and in making materiality assessments through management report. The paper shows the differences in the studied banks' Management reports, the standardized form of auditors' opinion regarding to Management report of banks and doubts about not fully understandability by users of financial statements.
\end{abstract}

Key words: Financial Reporting, Management report on financial statement, Banking audit, Auditors' opinion

JEL Codes: G21, G28, D82

\section{Introduction}

The interest to develop this study is based on the increasingly importance of the "disclosure" process in informing the users of audited financial statements of a company. According to the Cambridge Dictionary, the disclosure concept designates "the act of making something known or the fact that is made known", but in accounting and audit areas the term received many significations in the last years. The impossibility of a company to configure an exhaustive disclosure process could be easily supposed if we consider that disclosing information requires significant judgment regarding to what is important to be revealed to people/entities interested in different areas of a company. Establishing information to be disclosed does not mean that a company has to reveal secret information regarding managerial issues, costs of products, trade information etc. Unfortunately, there is no regular comprehensive disclosure framework that includes all relevant areas of activity of a company, even if we can identify some settlements established by different regulatory authorities in few domains, like environmental or financial aspects.

Over the years, disclosure financial information destined to inform users of the financial statements has evolved and expanded. Financial statement disclosure is based on financial reporting framework, that imposes companies to publish their annual financial statements (in Romania this requirement is contained by section 9.1 of OMPF no. 1802/2014 or point 17 of OMPF no. $1286 / 2012$ that state the companies' obligation to publish their approved financial statements,

1 “1 Decembrie 1918" University of Alba Iulia, Unirii Street, 15-17, Alba Iulia, Romania, Email: adelasocol@yahoo.com 
according to law. Also, the mentioned norm specifies the possibility that the users of financial statements can obtain a copy of financial statements at his/its request.)

But disclosing financial information is a concept more complex than what comprises disclosure of financial statements. It is a difficult trial to measure financial disclosure and reporting outcomes because companies have a multitude of means and methods to disclose information at their disposal, among them the Internet became preponderant since 2000, in the detriment of the letter published reports. Indeed the financial information that has to be disclosed is very complex and the disclosure process could become cumbersome, if we take into consideration that the rules and disclosure requirements have built up over many years. Natural questions are aimed at the relevance and utility of financial information provided by companies and the necessity to configure an adequate comprehensive legislative framework of information compulsory to be disclosed to the users.

Addressing disclosure in the audit of financial statements became an issue of high priority for international regulatory bodies, from which one stands out - the International Auditing and Assurance Standards Board IAASB. It became conscious of the role of disclosure in audit of financial statements and have realized a public consultation in 2011 regarding the disclosure and its audit implications, that represented the basis for the changes of the International Standards on Auditing in 2015.

The changes in the International Standards on Auditing ISAs were made for improving disclosures in the audit of financial statements that are considered (according ISA 200.13) "a structured representation of historical financial information, including disclosures, intended to communicate an entity's economic resources or obligations at a point in time, or the change therein for a period of time, in accordance with a financial reporting framework. Disclosure comprise explanatory or descriptive information, set out as required, expressly permitted or otherwise allowed by the applicable financial reporting framework, on the face of a financial statements, or in the notes, or incorporated therein by cross-reference". Auditors have to face up to the challenges of the new disclosure requirements of their duty for audits of financial statements for period ending on or after 15 December 2016.

A major topic of financial reporting framework of a company is the Management report, often known as Administrators' report, that is not part of financial statements, but it accompanies them for the approval of General Meeting of Shareholders. Auditors have to study the consistency of a separate Management report with the financial statements. According to the Directive 2013/34/EU (on the annual financial statements, consolidated financial statements and related reports of certain types of banks), auditors have to report through an opinion on whether the Management report is consistent with the financial statements for the same financial year, and whether the management report has been prepared in accordance with the applicable legal requirements. Also auditors have to state whether, in the light of the knowledge and understanding of the bank and its environment obtained in the course of the audit, he, she or it has identified material misstatements in the management report, and shall give an indication of the nature of any such misstatements.

A Corporate governance statement of a bank has to be included in the Management report or a separate governance report could be published with the Management report (according to article 20 of Directive 2013/34/EU). The statutory auditor have to report and express an opinion on the content of Corporate governance statement regarding the main features of the bank's internal control and risk management systems in relation to the financial reporting process and regarding the takeover bids (if bank is subject to that). Another aspects contained by the Corporate governance statement do not have to be audited and auditors only shall check if information has been provided.

For the moment, auditors should not report on the non-financial statement or the separate non-financial report, requested by Directive 2014/95/EU regarding the non-financial information of a company. Statutory auditors have only check if a non-financial statement or a separate non- 
financial report has been provided. If consider opportune, a state can require that the information included in the non-financial statement or in the separate report be verified by an independent assurance services provider.

\section{Objectives and methodology}

De jure comparability between Management reports of banks is accomplished, because all active banks from Romania apply the same set of reporting and disclosing standards, but this is not enough to achieve comparable banks' Management reports in practice. But de facto comparability is achieved if banks present their Management reports in the same template/format. Many factors can affect the factor comparability, as judgment made by preparers in elaborating banks' Management reports, different interpretation of the rules for banks' Management reports or options in implementing disclosure policies etc.

The main question for this research was: What were the significant elements of Management reports of first three banks from Romania for year 2015 that could influence the professional judgement of banking auditors in forming an opinion on financial statements of banks? Secondary questions were: Which types of information contained by Management reports of banks is appropriate and adequate with the legislative requirements? How can banks sustain the sensible information issued in their Management reports (e.g. forward-looking)? How must the auditors study the Management report in order to identify if the information is consistent with the financial statements?

The methodology used in the present paper belongs to content analysis approach, that is destined to investigate and interpret meanings of the content of Management reports of banks. The content analysis involves comparisons between first three banks by assets size from Romania based on their Management reports, that are published on the banks' web-sites. We focus on the data and intend to capture the sense of the banks' Management reports and also we sorted information into some category to identify the compliance with the legislative requirements for Management reports, but also to identify the differences or similarities between those three studied banks. In our paper, the comparative research methodology has been used to study the narrative or quantitative disclosure of banks and a qualitative evaluation of data was realized.

Our paper is consistent with other research on comparison between the disclosure issue of banks, based on different category of information that are disclosed - notes to the financial statements, public reports, the supplementary narrative commentary on amounts reported in the primary financial statements. Mandatory narratives on risk disclosure provided by banks in the two reports - the notes to the financial statements and the public report - are studied to assess the differences between these documents and to determine if any bank specific factors influence any differences found (Maffei M. et al., 2014). Comparability of financial statements over time and of companies operating within the same industry are considered to be the most important types of comparability and some authors studied a uniformity-flexibility dilemma in defining comparable financial statements and plead for the importance of preparers in elaborating of the financial statements (Cole V. et al., 2012). Research on another important type of disclosure - the supplementary narrative commentary on amounts reported in the primary financial statements suggests that companies are more inclined to provide supplementary narrative commentary on amounts reported in the income statement relative to the balance sheet amounts, raising doubt about whether companies provide a balanced assessment of company performance and position (Tauringana V. and Mangena M., 2014).

\section{Theoretical background}

Surveys on comparability of banks' Management reports and auditors' professional judgment on its are not so wide-spread in the economic literature. The authors prefer more general approaches on financial disclosure. An organization should disclose all the information in its possession that 
stakeholders would find useful in evaluating the organization and in making economic decisions regarding it. Management is responsible for preparing the published financial statements (and other reports) and external auditors are responsible for providing assurance that the financial statements do not contain material misstatements (Gaa, 2009). Therefore, the harmonization of financial reporting processes in the European Union is considered to be essential for proper operating of the capital market and for the creating an integrated financial services market in European Union (Păunescu M., 2015).

Some authors consider that since 2000 a new accounting and auditing framework in the European member states were developed, based on new disclosure policies proposed by IFRS, that make more than necessary the audit and monitoring of the validity and the quality of the information provided (Vrentzou E., 2011). Corporate governance has constituted a major subject of the economic field since 2000 years, when many studies were developed in order to analyze the corporate governance principles and guidelines. Also, in that time were published the incipient researches on the function of audit committee in the financial reporting process (Rezaee et al., 2003). The constitution of an audit committee improves the quality of financial statements (De Vlaminck N. and Sarens G., 2015), but some studies argue that only a third of the European states (EU or not EU) are included in their Corporate Governance code a recommendation for the implementation of internal audit function (Ivan, 2015).

These considerations suggest that the degree of audit harmonization (e.g. internal audit) still remains far away from the established target. Fortunately, is not the same situation in the accounting framework, that are more impregnated by common rules among European states. For example, beginning with the financial year that ended on 31 December 2012, the active banks from Romania applied the International Financial Reporting Standards IFRS. Pertinent literature suggests that the IFRS have been alleged to harmonise accounting processes as a step towards greater transparency, better accounting quality and comparability that will facilitate the widest possible access to investment capital across the European Union (Panayotis et al., 2016). Many reasons are incriminated for contributing to the development of the IFRS framework such as the priority to ensure comparability, consistency and transparency at the financial level. And these features have particularly expressed in the banking sector (Dandara, 2015), that is considered to be responsible for the stability of the financial system as a whole.

The global financial crisis has raised the importance of financial reporting in the banking industry once again (Gebhardt and Novotny-Farkas, 2011). Therefore the financial reporting of banks aroused attention of researchers in the last years and the topic of IFRS application in Romanian banks affects the financial reporting framework and constitutes a major actual theme studied by some authors (Gîrbină et al., 2012), that emphasize the benefits of IFRS reporting comparative with the major challenges of IFRS application, as such a complex nature of IFRS, insufficient application guidance, insufficient expertise in IFRS within the credit institution and adapting to frequent changes of IFRSs.

In 2014, the European Parliament and the Council published the Regulation EU no. $537 / 2014$ on specific requirements regarding statutory audit of public-interest entities, which specifies that good audit quality contributes to the orderly functioning of markets by enhancing the integrity and efficiency of financial statements. Also, the Directive 2014/56/EU of the European Parliament and of the Council on statutory audits of annual accounts and consolidated accounts was issued in 2014. Thus, statutory auditors fulfill an important societal role. These documents come into effect on 17 June 2016 and will apply to financial years starting on or after that date. The major aspects of audit reporting in the case of public-interest entities were clarified through these European normative mentioned provisions, that establish a complex reporting system in audit. The statutory auditor of a credit institution has to prepare the following types of reports that accompany the Audit report (Audit Report to the General Meeting of Shareholders) in its classical recognized form as ISA 700 (Forming an opinion and reporting on financial statements) requests: Additional 
Report to the Audit Committee of the credit institution, Reports to banking supervisors and Transparency report of auditor. Auditors present to the stakeholders the results of the audit through the Audit report and these new additional audit reports provide some detailed information to the audit committee of banks (explanations of audit results of the statutory audit regarding the methodology used, quantitative level of materiality, going concern considerations etc.) or to the competent authorities supervising banks (material breach of laws or other regulations which can affect the bank's activity, significant doubts concerning the future functioning of bank or qualified opinion for banks etc.).

According to the European Commission, only 57\% - 16 Member States have transposed Audit Directive (Directive 2014/56/EU) until the 17 of June 2016. The following states did not communicate any transposition measures of Directive: Belgium, Bulgaria, Croatia, Cyprus, Estonia, Greece, Latvia, Lithuania, Netherlands, Poland, Romania and Slovenia. Full transposition measures were communicated by Austria, Czech Republic, Denmark, Finland, France, Germany, Hungary, Ireland, Italy, Luxembourg, Malta, Portugal, Slovakia, Spain, Sweden and United Kingdom (European Commission, 2016).

The Council for Public Supervision of the Accounting Profession (CSIPPC), the Ministry of Public Finance (MFP) and the Chamber of Financial Auditors of Romania (CAFR) launched until the 7 of November 2016 a public debate of the implementation of the Directive 2014/56/EU in Romania. Now, there is a public project of law on statutory audits of annual accounts and consolidated accounts and even the initial date for transposition in Romanian legislation of Directive 2014/56/EU is passed, we hope that until the end of 2016 the law will be adopted.

\section{Data analysis}

First, in order to motivate our discussion on Management report / Administrators' report of banks, we start by considering current settlement on contents of Management report/ Administrators' report, as it is appointed in Directive 2013/34/EU (on the annual financial statements, consolidated financial statements and related reports of certain types of banks). According to the mentioned regulation (article 19), the Management report of banks shall include a fair review of the development and performance of the bank's business and of its position, together with a description of the principal risks and uncertainties that it faces. The review shall be a balanced and comprehensive analysis of the development and performance of the bank's business and of its position, consistent with the size and complexity of the business. To the extent necessary for an understanding of the bank's development, performance or position, the analysis shall include both financial and, where appropriate, non-financial key performance indicators relevant to the particular business, including information relating to environmental and employee matters. In providing the analysis, the management report shall, where appropriate, include references to, and additional explanations of, amounts reported in the annual financial statements. The management report shall also give an indication of:

- the bank's likely future development;

- activities in the field of research and development;

- the information concerning acquisitions of own shares (prescribed by Article 24(2) of Directive 2012/30/EU): the reasons for acquisitions made during the financial year; the number and nominal value or, in the absence of a nominal value, the accountable part of the shares acquired and disposed of during the financial year and the proportion of the subscribed capital which they represent; in the case of acquisition or disposal for a value, the consideration for the shares; the number and nominal value or, in the absence of a nominal value, the accountable par of all the shares acquired and held by the company and the proportion of the subscribed capital which they represent;

- the existence of branches of the bank; and in relation to the bank's use of financial instruments and where material for the assessment of its assets, liabilities, financial position and 
profit or loss: the bank's financial risk management objectives and policies, including its policy for hedging each major type of forecasted transaction for which hedge accounting is used; and the bank's exposure to price risk, credit risk, liquidity risk and cash flow risk.

Premises for a high degree of comparability between the three studied banks - first three banks by assets size from Romania in 2015 - should be fulfilled because all banks are active in Romania and apply the same rules in disclosing of Management report information. But high end comparability depends on circumstances in which banks apply the disclosure rules adapted to their concrete and unique situations. The disclosure framework in the Management report area shows several general requests referring to "fair review of the development and performance of the bank's business and of its position, together with a description of the principal risks and uncertainties that it faces". Such a settlement contributes to the lack of comparability, because banks are free to disclose information contributing to the requests, without being forced to inform about a certain type of information. As the concept of fair review of the development and performance of the bank's business and of its position or description of the main risks and uncertainties that it faces represent only generically expressed information, without the benefit of a rigid, non-discretionary and well established way to disclose information. Same considerations could be express for all rules applicable for content of Management report. Therefore, banks can provide narrative disclosure in their Management reports, without the safety that no other bank will have the same information as them. Otherwise, this hypothesis is confirmed by the analysis of the Management reports of those three studied banks.

Uniformity was the first issue in our comparison between banks. Initially, we confirm that the structure of the contents of banks are different, based on the data from table no. 1. Each bank has different sections on the basis of whom we can affirm that:

- Only bank 1 and bank 3 present macroeconomic considerations to delimit banking sector climate in 2015; 2015;

- Only bank 1 configures a separate section regarding the important events since the end of

- Bank 1 does not present a separate section on Corporate governance (but Management report details that more information regarding bank's Corporate Governance Code can be found on a separate link. Also, banks 1 describes in a separate section supervisory board, management board, and assets and liabilities committee in 2015). The other two banks include a separate section on Corporate Governance;

- All three banks disclose information about patrimony of bank in a separate section (from financial statements);

- All three banks have separate Risk management section;

- Bank 1 and bank 2 have separate section on Own funds disclosure / Capital management and adequacy;

- Bank 2 and bank 3 have a separate section on Corporate social responsibility;

- Only bank 1 and bank 3 have a section on Policy regarding environmental issues/ Environmental policy;

- Only bank 2 presents a separate section on Internal control framework;

- Only bank 3 develops a budgeted balance sheet and income statements for next year 2016.

These are not the exhaustive considerations on the uniformity of the Management reports of the three studied banks. Many other structural differences could be documented and explained, but we intend only to prove that the current rules in the area conduct to a non-uniformity of the contents of banks' Management reports. 


\section{Contents of Management reports of first three banks by assets size from Romania in 2015}

\begin{tabular}{|c|c|c|}
\hline $\begin{array}{l}\text { BANK 1 - Administrators' Report } \\
\text { Banca Comercială Română SA } 2015 \\
\text { 26 pages } \\
\text { A. Macroeconomic environment in } 2015 \\
\text { B. Important events since the end of } 2015 \\
\text { C. Romanian commercial bank's supervisory board, } \\
\text { management board, and assets and liabilities committee } \\
\text { structure during } 01.01 \text { - } 31.12 .2015 \\
\text { D. Patrimony of the Romanian commercial bank } \\
\text { E. Income statement for the year ended } 31 \text { December } \\
\text { 2015 } \\
\text { F. The bank's risk profile } \\
\text { G. Risk management } \\
\text { H. BCR policy regarding environmental issues } \\
\text { I. Own funds disclosure }\end{array}$ & $\begin{array}{l}\text { BANK 2- Annual Board of Directors' } \\
\text { Report BRD - Groupe Société } \\
\text { Générale } 2015 \\
\text { 1. The company and its shareholders } \\
\text { 2. Corporate governance } \\
\text { 3. Human resources } \\
\text { 4. Corporate and social responsibility } \\
\text { 5. Group activity and results } \\
\text { 6. Risk management } \\
\text { 7. Capital management and adequacy } \\
\text { 8. Internal control framework } \\
\text { 9. Board of directors' proposals } \\
\text { Appendix }\end{array}$ & $\begin{array}{l}\text { BANK 3- Report from the Board of Directors of } \\
\text { Banca Transilvania } 2015 \\
\text { Macroeconomic considerations } \\
\text { Banca Transilvania in 2015: objectives and } \\
\text { achievements } \\
\text { Business lines performances in } 2015 \\
\text { Bank's rating and financing sources } \\
\text { Banca Transilvania's network as at December } 31,2015 \\
\text { Economic and financial results in 2015 } \\
\text { Banking prudential ratios (CAMPL) } \\
\text { Proposals regarding } 2015 \text { profit distribution and share } \\
\text { capital increase } \\
\text { Corporate governance } \\
\text { Relations with shareholders and investors } \\
\text { Financial calendar for } 2016 \\
\text { Risk management } \\
\text { Banca Transilvania group policy } \\
\text { Members of BT Financial Group } \\
\text { Environmental policy } \\
\text { Corporate social responsibility } \\
\text { Other information } \\
\text { Subsequent events } \\
\text { Information about the projected evolution of the group } \\
\text { in 2016 } \\
\text { Investment plan for } 2016 \\
\text { Budgeted balance sheet and income statement for } 2016\end{array}$ \\
\hline
\end{tabular}

Source: Management reports of first three banks by assets size from Romania in 2015, web-sites www.bcr.ro, www.brd.ro,

www.bancatransilvania.ro 
We consider that the lack of formal comparability as it results from empirical study of the mentioned banks' Management reports affect de facto comparability between banks and their users of financial statements could be disorientated in the clutter of information when they read the banks' Management reports. Checking the formal and some material comparability mentioned above permits us to extend the consideration on the judgment of auditors, that have to study banks' Management report and its consistency with the financial statements. Auditors' duties are burden by heterogeneity of information issued in Management reports of banks and by the informal way to disclose information through Management report.

Sound and good quality judgment of auditors appears to be relevant in that situation when there is not one correct answer at a question, for example if such provisions from banks' Management reports contradict the financial statements that are the subject of audit. The ability and experience of auditors are decisive in making a professional judgment. Also, the professional skepticism is required when auditors could discover conditions which may indicate possible misstatements due to fraud or error.

When applying professional judgment to study the consistency of the Management report with the financial statements of banks, auditor should focus on matters that are significant and relevant to the users of financial statements. A professional judgment of auditors implies that they compare all provisions of banks' Management reports with the financial regulation and obtain additional information from elsewhere, as appropriate or necessary. Auditors must evaluate whether banks' assertions from Management reports are reasonable and are based on normative rules in obtaining the Management reports. Auditors have to realize a critical assessment of audit evidence, discuss with the management of banks and with they are charged with governance and decide if banks' options are similar with the auditors and if there are differences, auditors must discuss with banks and reflect on the implications for the audit report.

\section{Conclusions}

Management reports of banks that accompany financial statements provide financial and non-financial information relating especially to fair review of the development and performance of the bank's business and of its position, together with a description of the principal risks and uncertainties that it faces. Legislative norms asking banks to publish their Management report in the annual reports and a recent European Directive (2013/34/EU) and International Standards on Auditing require that auditors have to study the consistency of a separate Management report with the financial statements and they have to report through an opinion on whether the Management report is consistent with the financial statements for the same financial year, and whether the management report has been prepared in accordance with the applicable legal requirements. Also auditors have to state whether, in the light of the knowledge and understanding of the bank and its environment obtained in the course of the audit, he, she or it has identified material misstatements in the management report, and shall give an indication of the nature of any such misstatements.

The existence of the regulatory framework on elaborating and disclosing banks' Management reports and the auditors' opinion on its contribute to the expression of de jure comparability between banks, but de facto comparability still remains dependant of factors that imply judgment of preparers, interpretation of rules, options in implementing disclosure policies etc. We collected data from the annual reports of first three banks by assets size from Romania in 2015 in order to identify the features of their Management reports. The results reveal that the Management reports of all studied banks are not de facto comparable since banks can present in the different manners the requested information. Our results acknowledge that preparers of banks' Management report play an important role in disclosure of financial and non-financial information of banks. Such situation complicates the duties of banking auditors that have to decide the consistency of Management report with the financial statements provisions. 


\section{References}

1. Cole V., Branson J., Breesch D., 2012. The uniformity-flexibility dilemma when comparing financial statements: Views of auditors, analysts and other users, International Journal of Accounting and Information Management, Vol. 20(2), pp. 114-141.

2. Dandara D., 2015. Banking performance. IFRS and RAS comparative analysis for the Romanian banking system, Procedia Economics and Finance, 32, pp. 1148-1153.

3. De Vlaminck N., Sarens G., 2015. The relationship between audit committee characteristics and financial statement quality: evidence from Belgium, Journal of Management Governance, vol. 19 , pp. $145-166$.

4. Directive 2013/34/EU of the European Parliament and of the Council on the annual financial statements, consolidated financial statements and related reports of certain types of banks, amending Directive 2006/43/EC of the European Parliament and of the Council and repealing Council Directives 78/660/EEC and 83/349/EEC.

5. Directive 2014/56/EU of the European Parliament and of the Council on statutory audits of annual accounts and consolidated accounts (which amends the Statutory Audit Directive SAD 2006/53/EC).

6. Directive 2014/95/EU of the European Parliament and of the Council amending Directive 2013/34/EU as regards disclosure of non-financial and diversity information by certain large banks and groups.

7. European Commission, 2016. Monitoring implementation and enforcement of Directives, http://ec.europa.eu/finance/enforcement/directives/index_en.htm\#audit.

8. Gaa J.C., 2009. Corporate Governance and the responsibility of the Board of Directors for Strategic Financial Reporting, Journal of Business Ethics, Vol. 90, pp. 179-197.

9. Gebhardt G., Novotny-Farcas Z., 2011. Mandatory IFRS Adoption and Accounting Quality of European Banks, Journal of Business Finance \& Accounting, 38(3)\&(4), pp. 289-333.

10. Gîrbină M., Minu M., Bunea Ș., Săcărin M., 2012. Perceptions of preparers from Romanian banks regarding IFRS application, Accounting and Management Information Systems, Vol. 11(2), pp. 191-208.

11. International Auditing and Assurance Standards Board, 2015. Handbook of International Quality Control, Auditing, Review, Other Assurance, and Related Services Pronouncements.

12. Ivan R., 2015. An Internal Audit Perspective on Differences between European Corporate Governance Codes and OECD Pinciples, Academic Journal of Economic Studies, vol. 1, no.4, pp. 80-90.

13. Maffei M., Aria M., Fiondella C., Spano R., Zagaria C., 2014. (Un)useful risk disclosure: explanations from the Italian banks, Managerial Auditing Journal, Vol. 29(7), pp. 621-648.

14. Order of Ministry of Public Finances no. 1286 / 2012 for the approval the accounting regulations compliant with the International Financial Reporting Standards applicable to companies whose sucurities are admitted to trading on a capital market and for such internal control as management determines is necessary to enable the preparation and fair presentation of financial statements that are free form material misstatement, whether due to fraud or error.

15. Order of Ministry of Public Finances no. 1802/2014 for the approval of Accounting regulations regarding the individual financial statements and consolidated financial statements.

16. Panayotis M., Spathis C., Dasilas A., 2016. How institutional factors and IFRS affect the value relevance of conservative and non-conservative banks, Journal of Applied Accounting Research, Vol. 17(2), pp. 211-236.

17. Păunescu M., 2015. Implicaţii fiscale ale Standardelor Internaţionale de Raportare Financiară şi aplicarea IFRS 1, ASE Publishing House, Bucharest, p. 7.

18. Regulation EU no. 537/2014 on specific requirements regarding statutory audit of publicinterest entities. 
19. Rezaee Z., Olibe K.O., Minmier G., 2003. Improving corporate governance: the role of audit committee disclosures, Managerial Auditing Journal, vol. 18(6/7), pp. 530-537.

20. Tauringana V., Mangena M., 2014. Board structure and supplementary commentary on the primary financial statements, Journal of Applied Accounting Research, vol. 15(3), pp. 273290.

21. Vrentzou E., 2011. The effects of International Financial Reporting Standards on the notes of auditors, Managerial Finance, vol. 37(4), pp. 334-346. 